\title{
Horizontal Web Reinforcement Configuration Analysis of Deep Beam Capacity and Behavior using Finite Element Modeling
}

\author{
Agung Yoga Pranata \\ Department of Civil Engineering \\ Faculty of Engineering \\ Lambung Mangkurat University \\ Banjarmasin, Indonesia \\ agunglawliet24@gmail.com
}

\author{
Darmansyah Tjitradi \\ Department of Civil Engineering \\ Faculty of Engineering \\ Lambung Mangkurat University \\ Banjarmasin, Indonesia \\ tjitradi_syah@yahoo.com
}

\author{
Irfan Prasetia \\ Department of Civil Engineering \\ Faculty of Engineering \\ Lambung Mangkurat University \\ Banjarmasin, Indonesia \\ iprasetia@ulm.ac.id
}

\begin{abstract}
A deep beam is a beam with a small ratio of its shear span to its effective depth. Deep beams at failure under shear mechanism behave as brittle in contrast to the normal beams which become ductile under the flexural mechanism. The shear failure of deeps beams can be prevented by providing a sufficient amount of web shear reinforcements. Providing horizontal web reinforcement to the $\mathrm{RC}$ deep beams is a way to increase their capacity to shear. Testing of the studied deep beams was performed by Finite Element Method (FEM) modeling with the aid of ANSYS software. To obtain valid parameters for modeling RC deep beams in FEM modeling, calibrating test have to be done through verification and validation processes. The study results of all studied RC deep beams show that by closing up the spacing between the horizontal web reinforcement results in increment in the ultimate load, while the ultimate deflection and the curvature ductility were found to be decreasing. For RC deep beams, the placing configuration of horizontal web reinforcement at $0.5 \mathrm{~h}-0.7 \mathrm{~h}$ was found to be efficient for gaining higher values of ultimate deflection and curvature ductility compared to the placing configuration at $0.3 \mathrm{~h}-0.5 \mathrm{~h}$ with similar values of ultimate load. It was also found that all the specimens' crack patterns at the first crack state were caused by flexural-tension while at the ultimate state, they were caused by the shear mechanism.
\end{abstract}

Keywords-deep beam; horizontal web reinforcement; capacity; behavior; FEM

\section{INTRODUCTION}

A deep beam is a beam with a small ratio of shear span to effective depth. At failure, under shear, deep beams become brittle while normal beams, under flexural mechanism, become ductile. The general behavior of RC deep beams is dominated by the shear failure mechanism [1-4] and the non-linear stress for flexural and shear distribution [5]. Studies related to the horizontal web reinforcement of RC deep beams with the configuration by its space and its amount have been conducted by observations of its effect to increased shear strength [1,2,611]. This study attempts to investigate the effect of spacing and positioning configuration of horizontal web reinforcement of deep beams by monitoring capacity and curvature ductility.

\section{FINITE ELEMENT MODELING}

\section{A. Modeling Method}

Testing of studied deep beams was performed using FEM with the aid of ANSYS software. To obtain valid parameters for modeling RC deep beams in an FEM program, calibrating tests have to be done first (verification and validation). From the verification process [12-14] it is known that the element types for concrete, reinforcement steel model, and for the loading and the supporting plate are SOLID65, LINK8, and SOLID45 respectively. All ANSYS inputs for material and element types used in this study are referring to [12-14]. ANSYS input data for concrete and steel are shown in Tables I and II respectively. Models of concrete material and concrete modulus of elasticity used in this study are from the models in [15] and [16] respectively. The element types used for the modeling of the RC deep beam are shown in Figure 1.

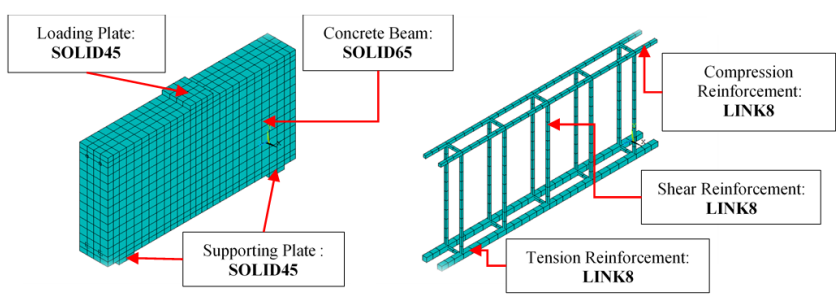

Fig. 1. Element types used for RC beams modeling in ANSYS

\section{B. Modeling Validation}

Validation process was conducted by modeling the experimental model from [2] using the A-2 specimen and the validation results shown in Figure 2. From the validation process, a similarity up to $80 \%$ for the value of load and deflection from the elastic state up to the peak load (ultimate state) was found. Similarity of shear crack pattern at failure was also found. 
TABLE I. ANSYS INPUT DATA - CONCRETE

\begin{tabular}{|c|c|c|c|c|}
\hline \multicolumn{5}{|c|}{ Nonlinear-multilinear kinematic hardening } \\
\hline \multicolumn{2}{|c|}{ Concrete compressive strength, $f_{c}^{\prime}$} & \multicolumn{3}{|c|}{$60 \mathrm{Mpa}$} \\
\hline \multicolumn{2}{|c|}{ Stress-strain model } & \multicolumn{3}{|c|}{$[15]$} \\
\hline \begin{tabular}{l|l} 
Strain, $\varepsilon_{c}$ &
\end{tabular} & Stress, $f_{c}$ & Strain, $\varepsilon_{c}$ & \multicolumn{2}{|c|}{ Stress, $f_{c}$} \\
\hline 0 & 0 & 0.00170 & \multicolumn{2}{|c|}{51.89520} \\
\hline 0.00010 & 3.26166 & 0.00190 & \multicolumn{2}{|c|}{55.78920} \\
\hline 0.00030 & 9.78462 & 0.00210 & \multicolumn{2}{|c|}{58.49680} \\
\hline 0.00050 & 16.30272 & 0.00230 & \multicolumn{2}{|c|}{59.85102} \\
\hline 0.00070 & 22.79813 & 0.00250 & \multicolumn{2}{|c|}{59.79919} \\
\hline 0.00090 & 29.22747 & 0.00270 & \multicolumn{2}{|c|}{58.42324} \\
\hline 0.00110 & 35.50903 & 0.00290 & \multicolumn{2}{|c|}{55.92581} \\
\hline 0.00130 & 41.51189 & 0.00310 & \multicolumn{2}{|c|}{52.58763} \\
\hline 0.00150 & 47.05119 & & & \\
\hline \multicolumn{2}{|c|}{ Elastic linear isotropic } & \multicolumn{3}{|c|}{ Concrete non-metal plasticity } \\
\hline \multirow{4}{*}{$\begin{array}{l}\text { Modulus of elasticity, } \\
\qquad E_{c}[16]\end{array}$} & \multirow{4}{*}{$32616 \mathrm{MPa}$} & \multicolumn{2}{|c|}{$\begin{array}{l}\text { Open shear transfer } \\
\text { coefficient, } \beta_{t}\end{array}$} & 0.2 \\
\hline & & \multicolumn{2}{|c|}{$\begin{array}{c}\text { Closed shear transfer } \\
\text { coefficient, } \beta_{c}\end{array}$} & 1.00 \\
\hline & & \multicolumn{2}{|c|}{$\begin{array}{l}\text { Uniaxial cracking } \\
\text { stress, } f_{r}\end{array}$} & 7.281 \\
\hline & & \multicolumn{2}{|c|}{$\begin{array}{l}\text { Uniaxial crushing } \\
\text { stress, } f_{c}^{\prime}\end{array}$} & 60 \\
\hline Poisson's ratio, $v_{c}$ & 0.2 & \multicolumn{2}{|c|}{ Tensile crack factor } & 0.60 \\
\hline
\end{tabular}
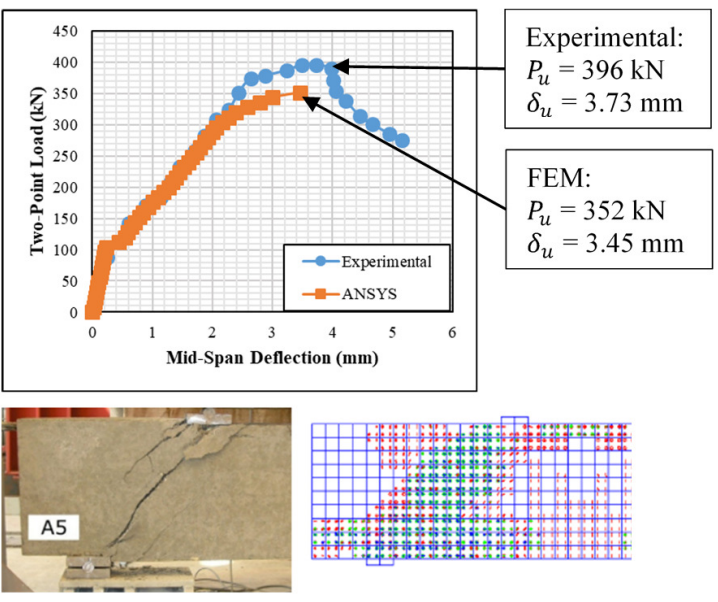

Fig. 2. FEM model validation by the experimental model
TABLE II. ANSYS INPUT DATA - REINFORCEMENT STEEL

\begin{tabular}{|c|c|c|c|}
\hline \multicolumn{2}{|c|}{ Elastic linear isotropic } & \multicolumn{2}{|c|}{ Nonlinear bilinear isotropic hardening } \\
\hline \multirow{3}{*}{$\begin{array}{c}\text { Modulus of } \\
\text { elasticity, } \boldsymbol{E}_{\boldsymbol{s}}\end{array}$} & \multirow{2}{*}{200000} & Reinforcement & $\begin{array}{c}\text { Yield stress, } \boldsymbol{f}_{\boldsymbol{y}} \\
\text { (MPa) }\end{array}$ \\
\cline { 3 - 4 } & & Tension & 585 \\
\cline { 3 - 4 } & & Compression & 433 \\
\cline { 3 - 4 } & 0.3 & Shear & 397 \\
\hline $\boldsymbol{v}_{\boldsymbol{c}}$ & Horizontal web & 397 \\
\hline
\end{tabular}

\section{STUDIED SPECIMENS}

All studied specimens had $150 \mathrm{~mm}$ width, $500 \mathrm{~mm}$ height, $1000 \mathrm{~mm}$ span, and $800 \mathrm{~mm}$ clear span. The reinforcements used for all specimens consisted of 2D22 for tension reinforcement, 2D13 for compression reinforcement, and 2D10-200 for shear reinforcement. The horizontal web reinforcement configuration used as a variable in this study is shown in Table III. The specimens used in this study were divided in two groups, consisting of series BT1 and BT2 respectively. Series BT1 are deep beams with the spacing configuration of the horizontal web reinforcement and are in turn divided into three series (BT1-1, BT1-2, and BT1-3). Series BT2 are derived from series BT1-2, and are deep beams with the position configuration of horizontal web reinforcement and are further divided into two series (BT2-1 and BT2-2). Specimen BT0 is the control specimen, which is a deep beam without horizontal web reinforcement.

TABLE III. REINFORCEMENT DETAILS OF STUDIED SPECIMENS

\begin{tabular}{|c|c|c|c|}
\hline $\begin{array}{c}\text { Specimen } \\
\text { (variable 1) }\end{array}$ & $\begin{array}{c}\text { Horizontal web } \\
\text { reinforcement }\end{array}$ & $\begin{array}{c}\text { Specimen } \\
\text { (variable 2) }\end{array}$ & $\begin{array}{c}\text { Horizontal web } \\
\text { reinforcement }\end{array}$ \\
\hline BT0 & - & BT2-1.1 & 2D6 $(0.3 \mathrm{~h}-0.5 \mathrm{~h})$ \\
\hline BT1-1.1 & 2D6-200 & BT2-1.2 & 2D10 $(0.3 \mathrm{~h}-0.5 \mathrm{~h})$ \\
\hline BT1-1.2 & 2D10-200 & BT2-1.3 & 2D13 $(0.3 \mathrm{~h}-0.5 \mathrm{~h})$ \\
\hline BT1-1.3 & 2D13-200 & BT2-2.1 & 2D6 $(0.5 \mathrm{~h}-0.7 \mathrm{~h})$ \\
\hline BT1-2.1 & 2D6-100 & BT2-2.2 & 2D10 $(0.5 \mathrm{~h}-0.7 \mathrm{~h})$ \\
\hline BT1-2.2 & 2D10-100 & BT2-2.3 & 2D13 $(0.5 \mathrm{~h}-0.7 \mathrm{~h})$ \\
\hline BT1-2.3 & 2D13-100 & & \\
\hline BT1-3.1 & 2D6-60 & & \\
\hline BT1-3.2 & 2D10-60 & & \\
\hline BT1-3.3 & 2D13-60 & & \\
\hline
\end{tabular}

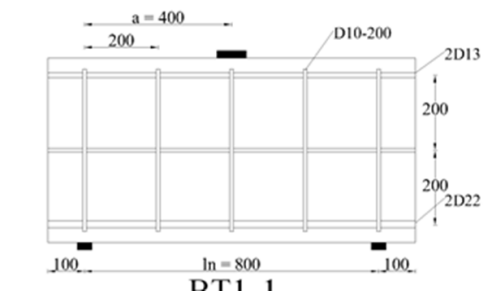

BT1-1

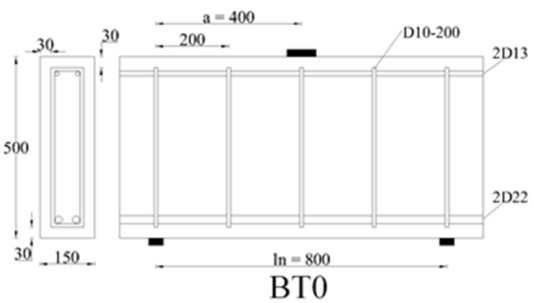

BT0

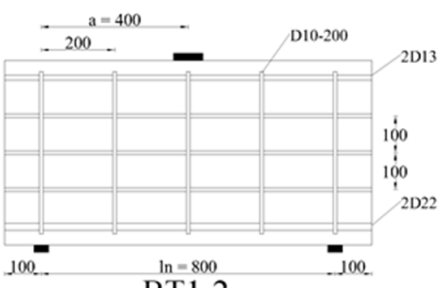

BT1-2

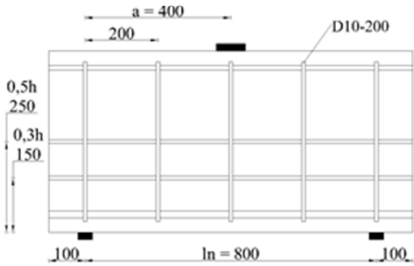

BT2-1
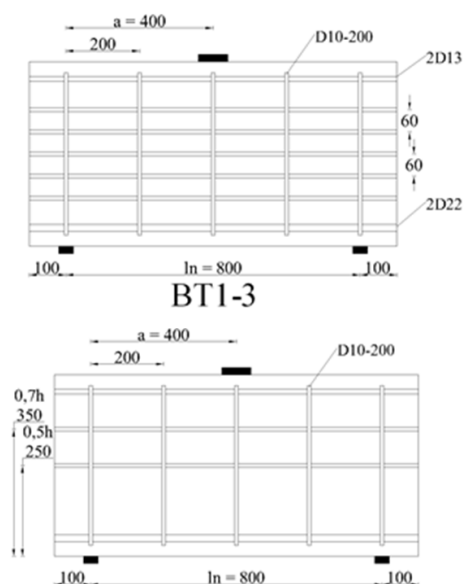

BT2-2

Fig. 3. Reinforcement details of studied specimens 


\section{RESULTS AND DISCUSSION}

\section{A. Load-Deflection Curves}

From Figure 4 it can be seen that the deep beam specimens become stiffer when the spacing closes up and the size of the horizontal web reinforcement enlarges. At the elastic state when the load is up to $324 \mathrm{kN}$, all the specimens had similar behavior and similar linear pattern of load-deflection curve.
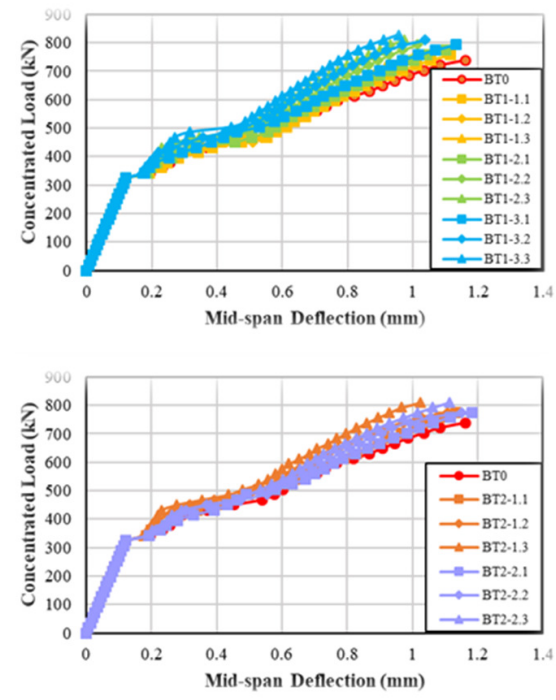

Fig. 4. Load-deflection curves of specimens at mid-span

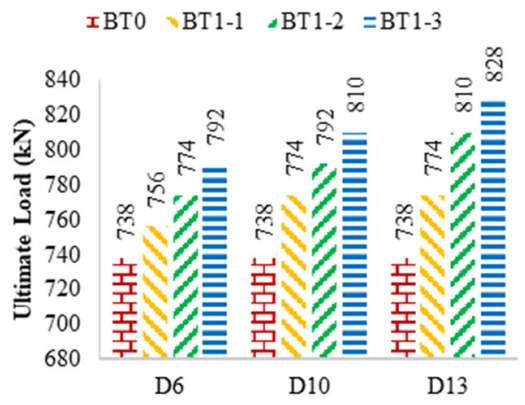

Size of Horizontal Web Reinforcement

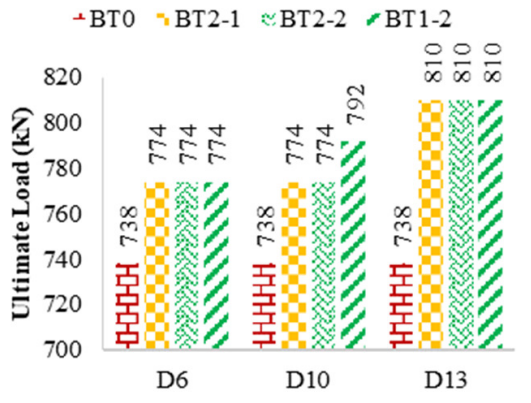

Fig. 5. Ultimate load of specimens
Figures 5 and 6 show the ultimate load and ultimate deflection of all studied specimens. Closing up the spacing and enlarging the size of horizontal web reinforcement results in ultimate load increase, while the ultimate deflection was found to be decreasing as shown in series BT1-1 to BT1-3. By configuring the position of horizontal web reinforcement at $0.3 \mathrm{~h}-0.5 \mathrm{~h}$ (series BT2-1) and at $0.5 \mathrm{~h}-0.7 \mathrm{~h}$ (series BT2-2) results in similar ultimate load, however the series BT2-2 have higher value of ultimate deflection compared to the series BT2-1.
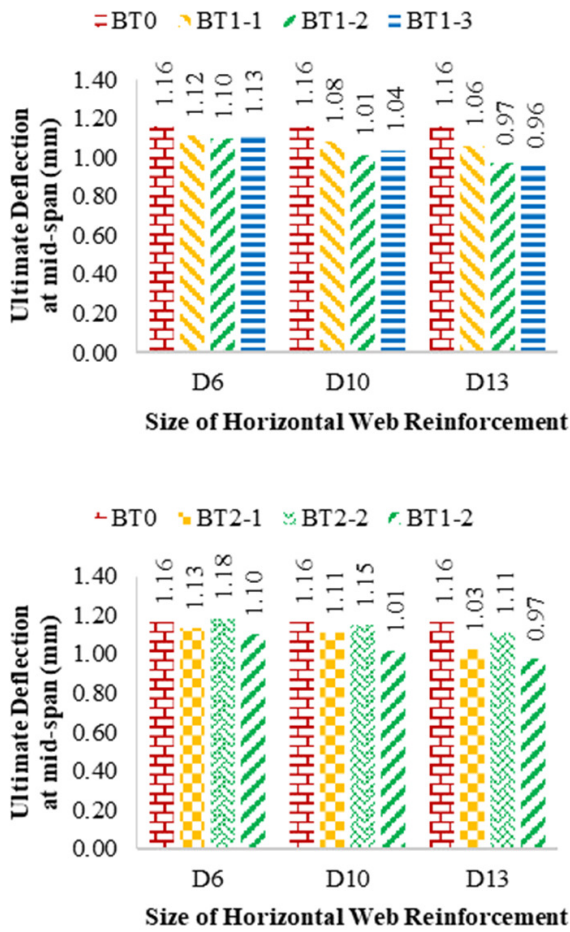

Fig. 6. Ultimate deflection at mid-dpan of specimens

\section{B. Curvature Ductility}

Curvature ductility was obtained by comparison of the value between ultimate curvature and yield curvature. The curvature value was obtained by converting the deflection to curvature using the Pythagorean equation used in [17]. The equation to calculate beam curvature ductility is:

$$
\begin{gathered}
R=\frac{y^{2}+l^{2} / 4}{2 y} \rightarrow \varphi=\frac{1}{R} \\
\mu=\frac{\varphi_{u}}{\varphi_{y}}
\end{gathered}
$$

From Figure 7 we can see that by closing up the spacing or by enlarging the area of horizontal web reinforcement, the value of curvature ductility decreases in series BT1-1 to BT1-3. Placing the horizontal web reinforcement around $0.5 \mathrm{~h}-0.7 \mathrm{~h}$ (series BT2-2) results in higher value of curvature ductility compared to series BT2-1.

\section{Concrete Compressive and Tensile Stress}

Concrete compression and tensile stress were taken at the 
mid span of the beam where the compression and the tensile mechanism occur. The concrete stress curve is shown in Figure 9. Compression and tensile stress curves had similar patterns for all specimens. The compression stress peak value found was around 20 to $25 \mathrm{MPa}$, quite far from the concrete compressive strength $f_{c}^{\prime}$ of $60 \mathrm{MPa}$. The tensile stress peak value found was around $7.1 \mathrm{MPa}$, which is close to the concrete modulus of rupture $f_{r}$ of $7.28 \mathrm{MPa}$. It was also observed that the increasing ratio of horizontal web reinforcement slightly increased the peak value of compression stress, but it had no effects on concrete tensile stress after the first crack occurrence, because the tensile stress was transferred to the tensile reinforcement.
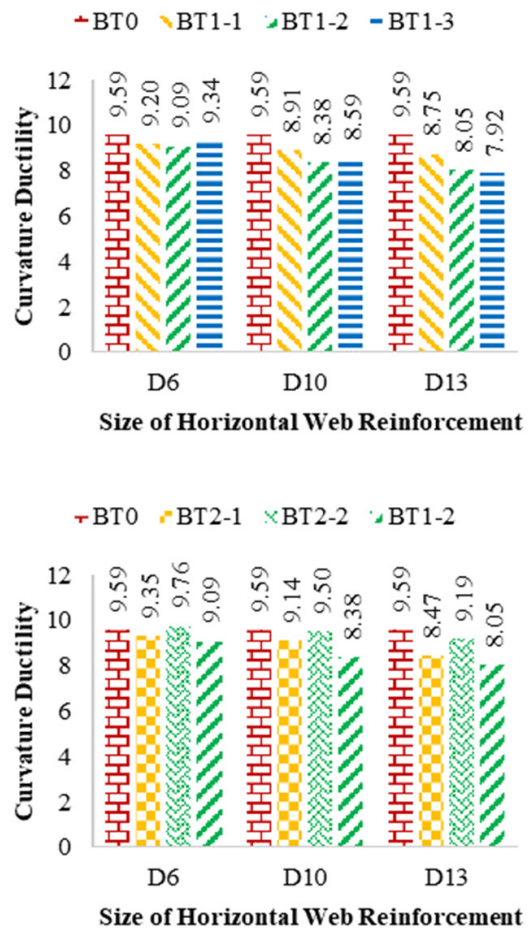

Fig. 7. Curvature ductility of specimens

\section{Concrete Stress and Crack Pattern}

Concrete stress and crack pattern were taken at first crack and ultimate state (Figure 8). At first crack state, when the load is $342 \mathrm{kN}$, tensile stress pattern formed at the bottom of the beam at mid-span with the flexural-tensile mechanism of crack pattern. The higher ratio of horizontal web reinforcement resulted in decrease of the spread of flexural-tension crack. First shear crack appeared when the load was between $432 \mathrm{kN}$ and $486 \mathrm{kN}$, and the higher ratio of horizontal web reinforcement resulted in delay in the appearance of the first shear crack. At ultimate state, stress pattern was formed at the shear span dominantly. At the shear span, stress pattern formed a diagonal shape which spread between loading and supporting plate under the mechanism of shear-compression. At the midspan, stress pattern and crack pattern spread from the bottom of the beam towards $0.5 \mathrm{~h}$ to $0.8 \mathrm{~h}$.

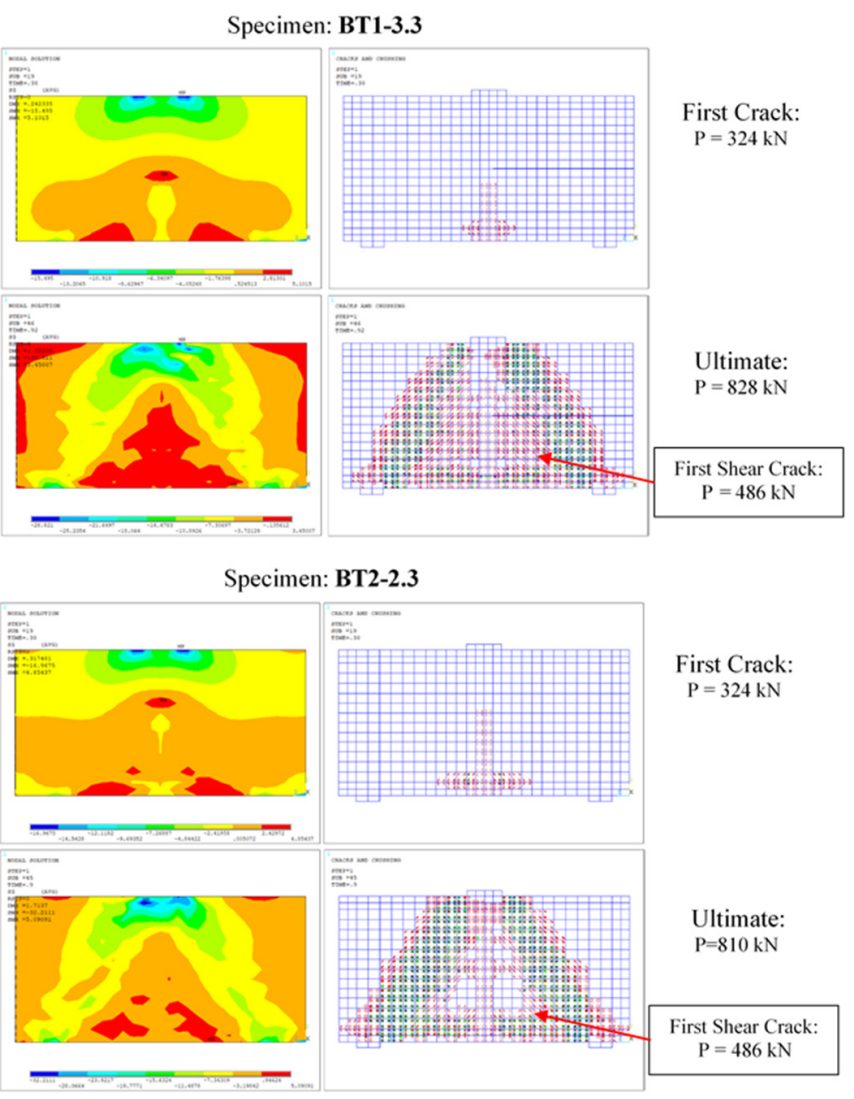

Fig. 8. Concrete stress and crack pattern of specimens

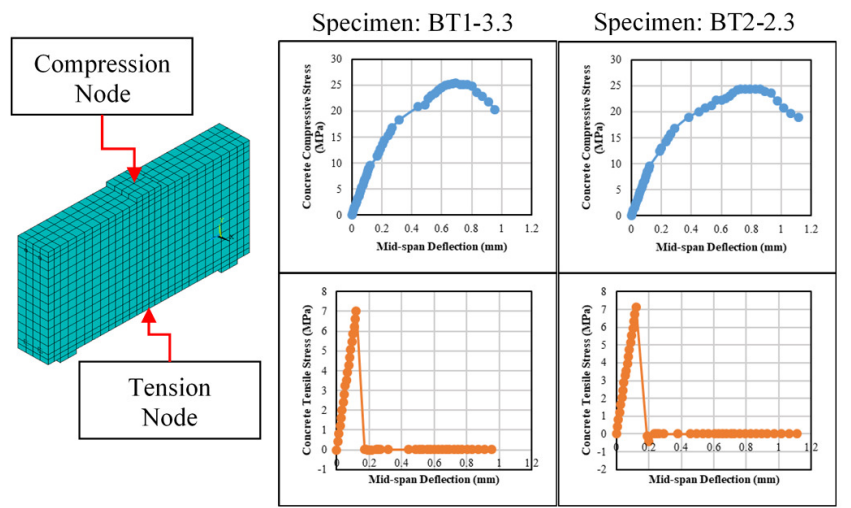

Fig. 9. Concrete compressive and tensile stress of specimens

\section{CONCLUSION}

The main conclusions of the performed study are:

- Closing up the spacing or enlarging the area of horizontal web reinforcement may lead to increase of the ultimate load and decrease of the ultimate deflection and curvature ductility of RC deep beams.

- Crack patterns and failure behaviors of all studied RC deep beam specimens had similar patterns at first crack (flexuraltension) and at ultimate state (shear-compression). 
- Obtaining efficient terms of ultimate load can be done by providing closer spacing and by enlarging the area of horizontal web reinforcement, but this impacts more stiffness to the beam. Obtaining efficient terms of curvature ductility can be done by configuring the position of horizontal web reinforcement at $0.5 \mathrm{~h}-0.7 \mathrm{~h}$, otherwise, by configuring the position of $0.3 \mathrm{~h}-0.5 \mathrm{~h}$ results in reduced value of curvature ductility.

\section{REFERENCES}

[1] G. Aguilar, A. B. Matamoros, G. J. Parra-Montesinos, J. A. Ramirez, J. K. Wight, "Experimental evaluation of design procedures for shear strength of deep reinforced concrete beams", ACI Structural Journal, Technical Paper No. 99S56, pp. 539-548, 2003

[2] A. Arabzadeh, R. Aghayari, A. R. Rahai, "Investigation of experimental and analytical shear strength of reinforced concrete deep beams", International Journal of Civil Engineering, Vol. 9, No. 3, pp. 207-214, 2011

[3] J. D. D. Garay-Moran, A. S. Lubell, "Behavior of deep beams containing high-strength longitudinal reinforcement”, ACI Structural Journal, Vol. 113, No. 1, pp. 17-28, 2016

[4] O. Q. Aziz, M. A. Ihsan, S. A. Yaseen, "Shear strength comparison of high performance reinforced concrete deep beams without stirrups between ANSYS vs experimental work", ZANCO Journal of Pure and Applied Sciences, Vol. 30, No. 1, pp. 73-84, 2018

[5] S. S. Patil, A. N. Shaikh, B. R. Niranjan, "Experimental and analytical study on reinforced concrete deep beam", International Journal of Mordern Engineering Research, Vol. 3, No. 1, pp. 45-52, 2013

[6] E. Rommel, "Pengaruh jumlah tulangan bagi dan arah sengkang pada kemampuan geser balok tinggi”, Jurnal Teknik Gelagar, Vol. 17, No. 1, pp. 17-25, 2006 (in Indonesian)

[7] E. Rommel, "Pemakaian perkuatan geser Longitudinal sebagai upaya peningkatan kapasitas balok tinggi beton bertulang", Jurnal Teknik Sipil, Vol. 13, No. 2, 2008 (in Indonesian)

[8] N. C. E. Yuliati, "Perilaku dan peningkatan kapasitas balok tinggi akibat perubahan rasio bentang geser terhadap tinggi efektif balok $(\mathrm{a} / \mathrm{d})$ ", Dinamika Teknik Sipil, Vol. 7, No. 1, pp. 30-36, 2007 (in Indonesian)

[9] K. Mohamed, A. S. Farghaly, B. Benmokrane, "Effect of web reinforcement in FRP-reinforced deep beams", The 7th International Conference on FRP Composites in Civil Engineering, Vancouver, Canada, August 20-22, 2014

[10] O. Q. Aziz, S. A. Yaseen, "Effect of type and position of shear reinforcement of high-strength reinforced concrete deep beams", AlRafidan Engineering, Vol. 21, No. 5, pp. 69-79, 2013

[11] M. A. Ihsan, O. Q. Aziz, S. A. Yaseen, "Shear strength prediction of high performance reinforced concrete deep beams with stirrups by ANSYS", Eurasian Journal of Science and Engineering, Vol. 3, No. 1, pp. 212-221, 2017

[12] D. Kachlakev, T. Miller, S. Yim, K. Chansawat, T. Potisuk, Finite Element Modeling of reinforced concrete structures strengthened with FRP laminates, Final Report SPR 316, Oregon Department of Transportation, 2001

[13] A. J. Wolanski, Flexural behavior of reinforced and prestressed concrete beams using Finite Element analysis, BSc Thesis, Marquette University, 2004

[14] D. Tjitradi, E. Eliatun, S. Taufik, "3D ANSYS numerical modeling of reinforced concrete beam behavior under different collapsed mechanisms", International Journal of Mechanics and Applications, Vol. 7, No. 1, pp. 14-23, 2017

[15] S. Popovics, "A numerical approach to the complete stress-strain curve of concrete", Cement and Concrete Research, Vol. 3, No. 5, pp. 583599,1973

[16] R. L. Carrasquillo, A. H. Nilson, F. O. Slate, "Properties of high-strength concrete subject to short-term loads", Journal of the American Concrete Institute, Vol. 78, No. 3, pp. 171-178, 1964
[17] S. Joshi, S. Paul, B. Balakrishnan, D. Menon, "Moment curvature relation of reinforced concrete T-beam sections: Numerical and experimental studies", Third International Conference on Advances in Civil, Structural and Construction Engineering, Rome, Italy, December $10-11,2015$ 